\title{
Development of Titanium-Sputtered Anodized Aluminum Substrates for Dye-Sensitized Solar Cells
}

\author{
MARIE-PIER CÔTÉ, NIMA PARSI BENEHKOHAL, NESLIHAN ALPAY, \\ GEORGE P. DEMOPOULOS, and MATHIEU BROCHU
}

\begin{abstract}
In this study, anodized aluminum coupons are sputtered with titanium and successfully demonstrated as dye-sensitized solar cell (DSC) electrode substrates in both anode [back-illumination (BI)] and cathode [front-illumination (FI)] configurations. The FI DSCs were found to be significantly more efficient than the BI devices registering an average efficiency of $5.7 v s 2.6$ pct. By comparison, the efficiency of benchmark cells built with fluorine-tin oxide-glass was 6.7 and 4.6 pct, respectively. The thickness of the titanium-sputtered film was varied from 0.85 to $1.1 \mu \mathrm{m}$ with the latter providing a better average efficiency when used as a counter electrode. According to preliminary stability testing, the Ti-sputtered anodized aluminum-based DSC devices exhibited a significant reduction of their efficiency over a period of 10 days that was partly attributed to triiodide redox electrolyte reaction with the aluminum substrate. This points to the need for optimization of the sputtered-titanium coating microstructure in order to completely isolate the aluminum substrate from the liquid electrolyte.
\end{abstract}

DOI: $10.1007 / \mathrm{s} 40553-014-0032-7$

(C) ASM International (ASM) and The Minerals, Metals, \& Materials Society (TMS) 2014

\section{INTRODUCTION}

TITANIUM is an attractive material for use as substrate in dye-sensitized solar cell (DSC) electrode fabrication due to its high conductivity and corrosion resistance. Titanium metal substrates have already been used in flexible electrode fabrication for DSC devices to replace rigid glass-based electrodes. ${ }^{[1-4]}$ In addition, Ti-coated steel substrates have been the subject of considerable R\&D effort. ${ }^{[5]}$ Alternatively, Ti-coated aluminum may provide a versatile less costly and lighter substrate for variable scale DSC applications, hence the undertaking of this research.

Dye-sensitized solar cells mounted on light aluminum substrates may offer some unique advantages in various applications and especially in buildings and transportation. This is so because of the broad use of aluminum in these sectors as well as because of the inherent simplicity of DSC fabrication (roll-to-roll processing) that does not require complex and energy intensive high temperature vacuum processes. Moreover, DSCs perform better than the other types of photovoltaic cells under diffuse lighting conditions including artificial light. ${ }^{[6]}$ Furthermore, the most attractive advantage of DSCs over silicon cells remains the possibility of fabricating building-integrated and non-flat devices. A lot of research has been done in that direction in order to

MARIE-PIER CÔTÉ, Master Student, NIMA PARSI BENEHKOHAL, Post Doctoral Fellow, NESLIHAN ALPAY, Ph.D. Student, GEORGE P. DEMOPOULOS, Professor, and MATHIEU BROCHU, Associate Professor, are with the Department of Mining and Materials Engineering, McGill University, 3610 University Street, Montreal, QC H3A 0C5, Canada. Contact e-mail: Mathieu.brochu@ mcgill.ca

Manuscript submitted April 6, 2014.

Article published online October 29, 2014 replace the flat and brittle conventional glass substrate used in DSCs by either polymeric ${ }^{[7-14]}$ or metallic ${ }^{[5,15-23]}$ electrodes. Moreover, the transparent conductive oxide (TCO)-glass typically used in DSCs represents a major part of their $\operatorname{cost}^{[24]}$ and is the component that has the largest negative impact on the environment due to its complex fabrication process. ${ }^{[25]}$ Thus, replacing TCOglass by metallic substrates can potentially render DSCs very attractive for building or automotive applications both economically and environmentally.

However, the development of metallic electrodes for liquid electrolyte-type DSCs is a challenge due to corrosion attack by the iodide/triiodide redox couple. A number of studies have been conducted in order to identify the metals that are resistant to reaction with the iodide/triiodide electrolyte. ${ }^{[15,19,20,22,26]}$ Of the metals studied, titanium, ${ }^{[20,22]}$ stainless steel, ${ }^{[15,19,20,22]}$ and Inconel ${ }^{[20]}$ were found to be stable but not polished/ abraded aluminum. ${ }^{[22,26]}$

Of the above three identified as stable metals, titanium and inconel are very expensive to offer a viable option for building-integrated photovoltaics, ${ }^{[27]}$ hence the focus on stainless steel. ${ }^{[5]}$ But beyond steel, aluminum is a major construction material ${ }^{[28,29]}$ that needs to be properly engineered as viable substrate for BIPV application. For example, just in Western Europe 200,000 tons of rolled aluminum were used for building applications in 2006 and this number keeps increasing. ${ }^{[30]}$ In addition to the corrosion problem cited above, another reason that complicates the use of aluminum as substrate for DSCs in BIPV applications stems from the fact that aluminum is generally anodized before being used in buildings. The alumina layer produced by anodization has a high electrical resistance that prevents conduction toward the aluminum substrate. 
It is the scope of the present study to address these two limiting factors of aluminum as substrate for DSC, i.e., the corrosion and electrical resistance issues, by resorting to a two-step thin film surface engineering approach. According to this new approach, the aluminum substrates are first anodized, followed by sputtering of a titanium layer that is used as a conduction layer, mimicking the TCO-glass concept. These Ti-coated anodized aluminum substrates are investigated both as counter electrodes and photo-anodes paired with FTOglass electrodes.

\section{MATERIALS AND METHODS}

\section{A. Aluminum Substrate}

A 3.2-mm-thick AA 1100 plate was used as the base material for the electrode substrate. Samples of $4.5 \mathrm{~cm}$ by $2.5 \mathrm{~cm}$ in dimension were first polished down to 1200 grit grinding paper in order to eliminate surface defects created during rolling and handling. The samples were then pre-treated by immersion in a $2.5 \mathrm{M}$ sodium hydroxide solution at $328 \mathrm{~K}\left(55^{\circ} \mathrm{C}\right)$ for 30 seconds to remove the native aluminum oxide layer and subsequently immersing in a $2.4 \mathrm{M}$ nitric acid solution at room temperature for 30 seconds to activate the aluminum surface. ${ }^{[31]}$ The samples were rinsed with water and methanol and dried after each pre-treatment step. The pre-treated samples were then anodized over a $9 \mathrm{~cm}^{2}$ area in $0.3 \mathrm{M}$ oxalic acid solution at $293 \mathrm{~K}\left(20^{\circ} \mathrm{C}\right)$ under a DC potential of $30 \mathrm{~V}$ for 30 minutes.

\section{B. Titanium Sputtering}

The anodized aluminum substrates were cleaned with methanol prior to sputtering. The titanium thin films, serving as current carrier for the cell, were deposited using a Denton E14 DC sputterer in an 8 mTorr argon atmosphere at room temperature. The current used was $0.6 \mathrm{~A}$ resulting in a deposition rate of approximately $1.75 \AA / s$ as verified with titanium sputtering on flat glass control substrate using a stylus profilometer. Two different thickness titanium films were prepared, namely 0.85 and $1.1 \mu \mathrm{m}$. These thickness values are an average of 10 samples. From this point forward, these titaniumsputtered anodized aluminum substrates are simply called metal substrates.

\section{DSC Fabrication}

Prior to the cell fabrication, holes were drilled in the fluorine-tin oxide (FTO)-glass substrates, which were then cleaned with micro-90 soap in an ultrasonic bath for 30 minutes and further rinsed with ethanol and dried. The metal substrates were simply wiped with ethanol.

A $50-\mu \mathrm{m}$ thick mask with an area of $1 \mathrm{~cm}^{2}$ was applied on the conductive surface of the photo-anode substrates, either FTO-glass or metal substrates depending on the configuration used, i.e., front (FI) or back (BI) illumination, to ensure reliable measurements. ${ }^{[32]}$ The two configurations are shown in Figure 1. A
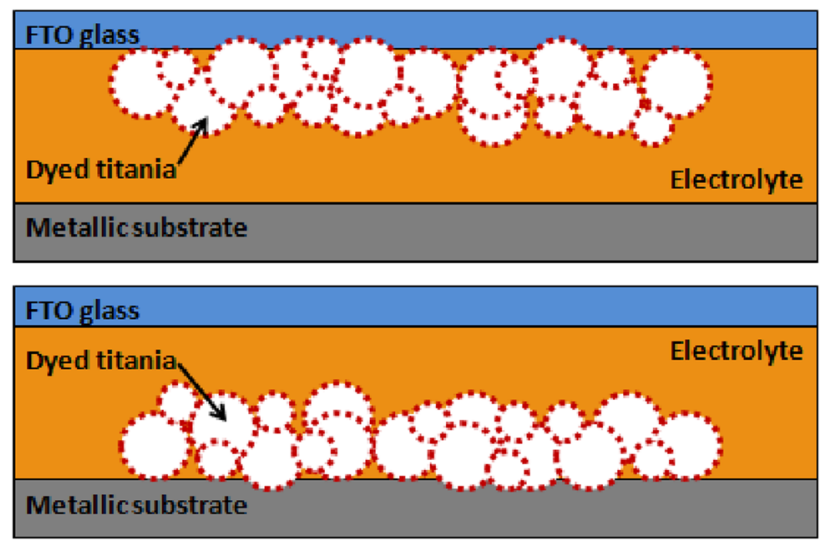

Fig. 1-Front-illumination (top) and back-illumination (bottom) configurations in which the $\mathrm{TiO}_{2}$ film is on the FTO-glass substrate and on the metal substrate, respectively.

commercially available $\mathrm{TiO}_{2}$ paste (Dyesol 18NRT) was applied using the doctor blading technique and sintered at $723 \mathrm{~K}\left(450{ }^{\circ} \mathrm{C}\right)$ for 30 minutes according to the following protocol: $393 \mathrm{~K} / \mathrm{h}\left(120^{\circ} \mathrm{C} / \mathrm{h}\right)$ up to $423 \mathrm{~K}$ $\left(150{ }^{\circ} \mathrm{C}\right), 15$ minutes at $423 \mathrm{~K} \quad\left(150{ }^{\circ} \mathrm{C}\right), \quad 513 \mathrm{~K} / \mathrm{h}$ $\left(240{ }^{\circ} \mathrm{C} / \mathrm{h}\right)$ up to $598 \mathrm{~K}\left(325^{\circ} \mathrm{C}\right), 5$ minutes at $598 \mathrm{~K}$ $\left(325^{\circ} \mathrm{C}\right), 393 \mathrm{~K} / \mathrm{h}\left(120^{\circ} \mathrm{C} / \mathrm{h}\right)$ up to $648 \mathrm{~K}\left(375^{\circ} \mathrm{C}\right)$, 5 minutes at $548 \mathrm{~K}\left(275^{\circ} \mathrm{C}\right), 333 \mathrm{~K} / \mathrm{h}\left(60^{\circ} \mathrm{C} / \mathrm{h}\right)$ up to $723 \mathrm{~K}\left(450{ }^{\circ} \mathrm{C}\right), 30$ minutes at $723 \mathrm{~K}\left(450^{\circ} \mathrm{C}\right)$, and cooling down to room temperature at $333 \mathrm{~K} / \mathrm{h}\left(60^{\circ} \mathrm{C} /\right.$ h). The thickness of the $\mathrm{TiO}_{2}$ films was measured using a stylus profilometer and only the anodes with $\mathrm{a} \mathrm{TiO}_{2}$ film thickness between 8 and $12 \mu \mathrm{m}$ were further used. Finally, the anodes were immersed in a ruthenium-based dye (N719, Dyesol) for 24 hours. The freshly sensitized anodes were rinsed with ethanol and dried before assembled immediately after.

The counter electrodes were prepared by depositing a drop of $5 \mathrm{nM} \mathrm{HPtCl}_{6}$-propanol on the conductive surface of the substrates and heating at $723 \mathrm{~K}$ $\left(450{ }^{\circ} \mathrm{C}\right)$ for 30 minutes.

The electrodes were sealed first together at $398 \mathrm{~K}$ $\left(125^{\circ} \mathrm{C}\right)$ using a $60-\mu$ m-thick thermoplastic (Surlyn-60, Dyesol) gasket. The iodide/triiodide electrolyte solution was injected in the hole drilled in the glass electrode using a fine-tip pipette. The holes were sealed with microscope glass slides using 30- $\mu \mathrm{m}$-thick thermoplastic (Surlyn-30, Dyesol). Indium films acting as current collectors were soldered on the FTO face of the glass electrodes.

In total, ten DSC devices were fabricated and tested for each type of electrode, "thick titanium," "thin titanium," and "FTO-glass." In each case, five DSCs were fabricated in the front-illumination (FI) configuration and five in the back-illumination (BI) configuration, i.e., five DSCs with the FTO-glass substrate used as an anode and five as a cathode, respectively.

\section{Microstructural and Cell Performance Characterization}

The microstructure of the alumina layer formed by anodization and the sputtered-titanium layer of all substrates was characterized using a Hitachi S-4700 
field emission scanning electron microscope. The PV performance of all the DSCs was characterized over a period of 10 days using a PV Measurements Inc. ABA solar simulator providing $1000 \mathrm{~W} / \mathrm{m}^{2}$ (AM1.5 solar emission) equivalent light provided by a Xenon lamp calibrated with a reference silicon cell. The electrochemical impedance spectroscopy spectra (EIS) were collected on the cell assembly day on two DSCs of each type using a VSP-potentiostat system from BioLogic under $1000 \mathrm{~W} / \mathrm{m}^{2}$ illumination, applying a $10 \mathrm{mV}$ AC signal and scanning at a frequency ranging between $400 \mathrm{kHz}$ and $10 \mathrm{mHz}$ at different applied biases. The EIS data were analyzed with the Zview software.

\section{RESULTS AND DISCUSSION}

\section{A. Ti-Sputtered Anodized Aluminum Electrode Characterization}

The anodization of the aluminum substrate produced a porous layer of about $2 \mu \mathrm{m}$ in thickness, resulting in a growth rate of about $0.07 \mu \mathrm{m} / \mathrm{min}$, which is in the same order of magnitude as what is reported for oxalic acid anodization under these conditions. ${ }^{[33-35]}$ The sputteredtitanium layer thickness measured on the glass control samples was $0.835 \pm 0.025$ and $1.09 \pm 0.06 \mu \mathrm{m}$ for the two tested times, and will be called 0.85 and $1.1 \mu \mathrm{m}$

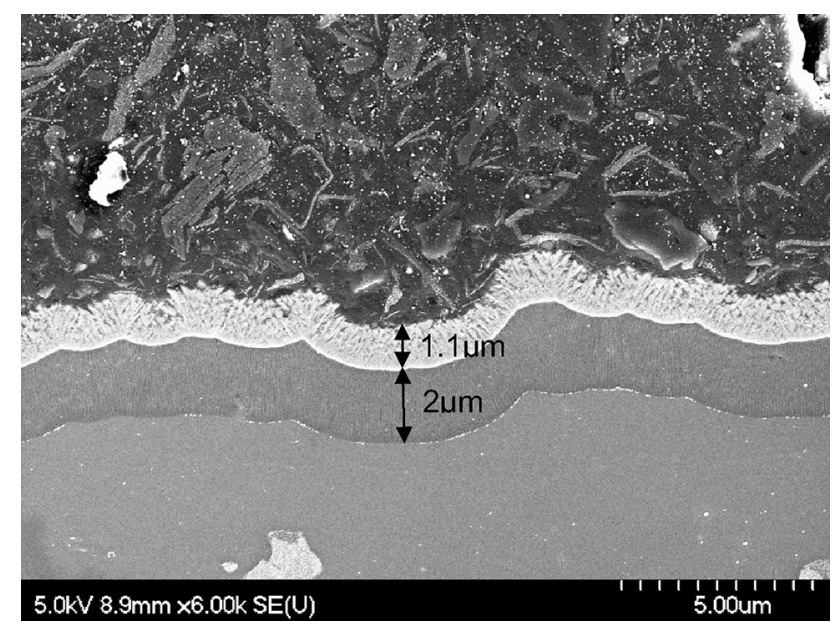

Fig. 2-SEM cross-section of a metal substrate showing the aluminum substrate, the $2-\mu \mathrm{m}$-thick porous alumina layer and the $1.1-\mu \mathrm{m}-$ thick sputtered-titanium layer. The layer over the $1-\mu \mathrm{m}$-thick titanium layer is bakelite, used for sample mounting. from here on. Figure 2 shows the cross-section of a typical $1.1-\mu \mathrm{m}$ titanium-sputtered anodized sample. As it can be seen the titanium-sputtered layer grew in a columnar manner, which is a common feature for films deposited with a high sputtering rate. ${ }^{[36-39]}$

\section{B. Efficiency Analysis}

Table I presents the average power conversion efficiencies measured on the DSCs within 30 minutes of assembly and the maximum value obtained for each type of DSC. First, it can be seen from these results that the DSCs based both on titanium-sputtered anodized aluminum electrodes and FTO-glass electrodes show a statistically greater average efficiency in the FI configuration than in the BI configuration. In fact, the $1.1-\mu \mathrm{m}$ titaniumaluminum-based DSCs show an average efficiency of $5.7 \pm 0.5$ and $2.6 \pm 0.4$ pct in the FI and BI configurations, respectively, which represents a difference of 54 pct. Similarly, an average difference of 24 and 31 pct was observed between the FI and the BI configuration for $0.85-\mu \mathrm{m}$ titanium-aluminum-based DSCs and reference glass DSCs, respectively. The maximum measured values also exhibit the same trend. This behavior is expected since the incident light has to go through a layer of electrolyte before reaching the sensitized $\mathrm{TiO}_{2}$ film in the BI configuration DSCs (see Figure 1). It was shown by Ito et $a{ }^{[1]}$ that the iodide/triiodide electrolyte cuts the incident light significantly in the range from 400 to $600 \mathrm{~nm}$, thus reducing the amount of photons reaching the dye molecules and subsequently reducing the efficiency of the DSC. Moreover, the standard N719 dye has its main absorbance peak for light around $530 \mathrm{~nm},{ }^{[40]}$ which is in the range of wavelengths cut by the electrolyte. In the most efficient configuration (FI), the thicker titanium film results in a greater average efficiency compared to the thinner film due to lower electrical resistance as a result of denser and less "patchy" deposit: $5.7 \pm 0.5$ pct compared to $3.8 \pm 0.1$ pct. Future work can lead to further efficiency increases via alteration of sputtering conditions to produce even higher density $\mathrm{Ti}$ deposit without necessarily excessively increasing its thickness that is not economically desirable. Finally, the results show that all the DSCs based on metallic electrodes have a lower efficiency than the reference FTOglass DSCs, which is usually the case for other reported metal-based DSCs. ${ }^{[1,5,16,17,19,20]}$

Figure 3 shows current-voltage curves for the best DSCs with both titanium thicknesses and for both configurations, respectively. It can be seen on this graph

Table I. Average Efficiency Data for DSCs Mounted on Titanium-Sputtered Anodized Aluminum Substrates or FTO-Glass Substrates at One Sun Illumination

\begin{tabular}{|c|c|c|c|c|c|c|}
\hline & \multicolumn{2}{|c|}{ Thin Ti Film } & \multicolumn{2}{|c|}{ Thick Ti Film } & \multicolumn{2}{|c|}{ FTO-Glass } \\
\hline & Max Efficiency & Average Efficiency & Max Efficiency & Average Efficiency & Max Efficiency & Average Efficiency \\
\hline Front-illumination & 4.2 & $3.8 \pm 0.1$ & 6.3 & $5.7 \pm 0.5$ & 7.4 & $6.7 \pm 0.4$ \\
\hline Back-illumination & 3.0 & $2.9 \pm 0.2$ & 3.1 & $2.6 \pm 0.4$ & 5.2 & $4.6 \pm 0.4$ \\
\hline
\end{tabular}

A $0.16 \mathrm{~cm}^{2}$ mask was used for the efficiency measurements. ${ }^{[32]}$ The outliers were removed from the statistics (1 outlier for both BI and FI with thin Ti film). 


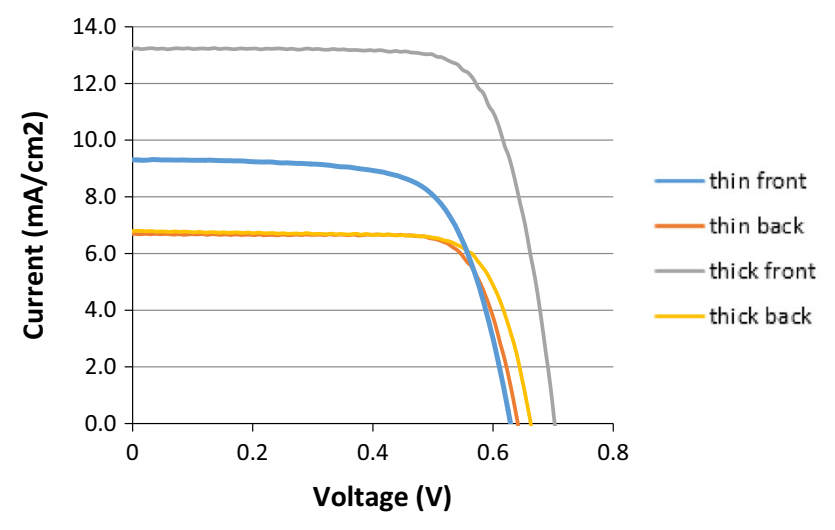

Fig. 3- $J-V$ curves of DSCs based on 1.1 - and $0.85-\mu$ m-thick titanium films in FI and BI configurations. A $0.16 \mathrm{~cm}^{2}$ mask was used for the measurements.

that the best BI DSCs have a similar behavior independently of the titanium thickness. On the other hand, the behavior of the best FI DSCs varies with the titanium thickness. As a matter of fact, an increase of approximately 5 and 30 pct is observed in the open circuit voltage and the short-circuit current density, respectively. Also Figure 3 makes it obvious that the BI DSCs show a lower overall conversion efficiency than FI cells due once again to a decrease in open circuit voltage of the order of 5 pct accompanied by an even greater decrease in short-circuit current of the order of 50 and 30 pct, when compared to the best 1.1 - and $0.85-\mu \mathrm{m}-$ thick titanium FI DSCs, respectively.

\section{Electrochemical Impedance Spectroscopy Analysis}

Figure 4 shows the typical EIS spectrum of one of the Ti-sputtered anodized Al-based DSCs. Here, only the EIS of one cell type (thick film BI) is shown, but similar spectra for all cell types were generated and analyzed using the equivalent circuit shown in Figure 5. With the help of the latter circuit, the average values of the different resistances could be determined. The $R_{\mathrm{CE}}$ component of the equivalent circuit is presented in the spectra as the width of the first semi-circle (high frequency region) and $R_{\text {rec }}$ as the width of the second semi-circle (low frequency region). The $R_{\mathrm{s}}$ component is represented on the spectra by the distance between the $y$-axis and the first semi-circle. ${ }^{[42]}$ The average values of $R_{\mathrm{CE}}, R_{\mathrm{rec}}$, and $R_{\mathrm{s}}$ for each type of DSCs are summarized in Table II. Of the three resistances calculated $\left(R_{\mathrm{CE}}\right.$, $R_{\text {rec }}, R_{\mathrm{s}}$ ), the series resistance, $R_{\mathrm{s}}$, proved to better relate to the PV performance of the different cell types built. Thus, as it can be seen from the data in Table II, the series resistance of DSCs based on $1.1-\mu \mathrm{m}$-thick titanium films is lower than that of DSCs based on $0.85 \mu \mathrm{m}$ thick titanium films in direct correspondence with the higher efficiency and current output of the former type (see data in Table I).

\section{Analysis of Cell Stability}

The medium-term stability of the sputtered-titaniumanodized aluminum-based DSCs was tested by measur-

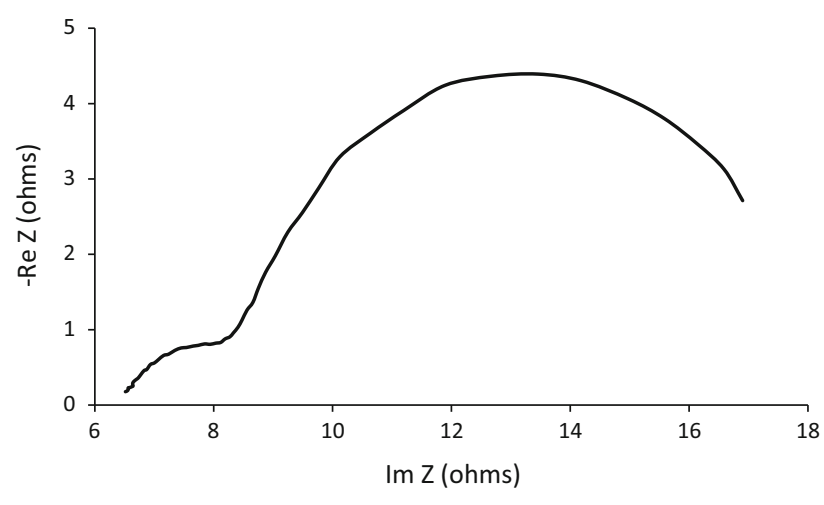

Fig. 4-Typical Nyquist plot of titanium-sputtered anodized aluminum DSC measured under one sun illumination and the $V_{\mathrm{oc}}$ condition. This plot is for the $1.1-\mu$ m-thick titanium-coated anodized aluminum BI DSC device.

ing their efficiency daily over a period of 10 days at room temperature. Characteristic cell degradation performance data in the form of average efficiency as a function of time are shown in Figure 6 for $1.1-\mu \mathrm{m}$-thick titanium-aluminum and glass-based DSCs. The FI and BI titanium-aluminum-based DSCs showed a gradual reduction in their efficiency along with a change in the color of the electrolyte from dark orange to colorless over time. Knowing that the triiodide ions confer the orange color to the electrolyte, this loss of color in the electrolyte is attributed to the reduction of triiodide ions to iodide ions $\left(\mathrm{I}_{3}{ }^{-}+2 \mathrm{e}^{-} \rightarrow 3 \mathrm{I}^{-}\right),{ }^{[19,22]}$ which in turn causes a reduction in the regeneration rate of the DSC and its cell efficiency. The observed color change apparently indicates that a given portion of the titanium-sputtered anodized aluminum electrodes, either aluminum or titanium, reacts with the triiodide ions thus causing a reduction in the cell's efficiency. Since Ti has proven previously to be resistant to corrosion attack, it must therefore be the anodized aluminum substrate that reacted. It is postulated that due to porosity arising from the columnar structure of the titanium-sputtered film (see Figure 2), the electrolyte penetrated the titanium film and reached the underlying anodized aluminum substrate. Anodization should have provided corrosion resistance to the underlying aluminum metal. However, when an anodized aluminum coupon was observed with an SEM after it had been heated at $723 \mathrm{~K}\left(450{ }^{\circ} \mathrm{C}\right)$ for 30 minutes as prescribed for the sintering of the nanotitania film, it was found with its anodized alumina layer to have cracked due to the different thermal expansion coefficients of aluminum and alumina. The surface of the cracked alumina layer is shown in Figure 7. Therefore, the alumina layer, which was expected to protect the aluminum substrate, due to cracks seems to have allowed the electrolyte to reach the base aluminum which is known to be prone to corrosion attack by triiodide ions. ${ }^{[22]}$

Consequently, further optimization of the fabrication process is required in order to increase the density of the titanium layer either by performing a post-treatment or by modifying the sputtering conditions. The cracking issue should also be addressed by modifying the sintering protocol. 


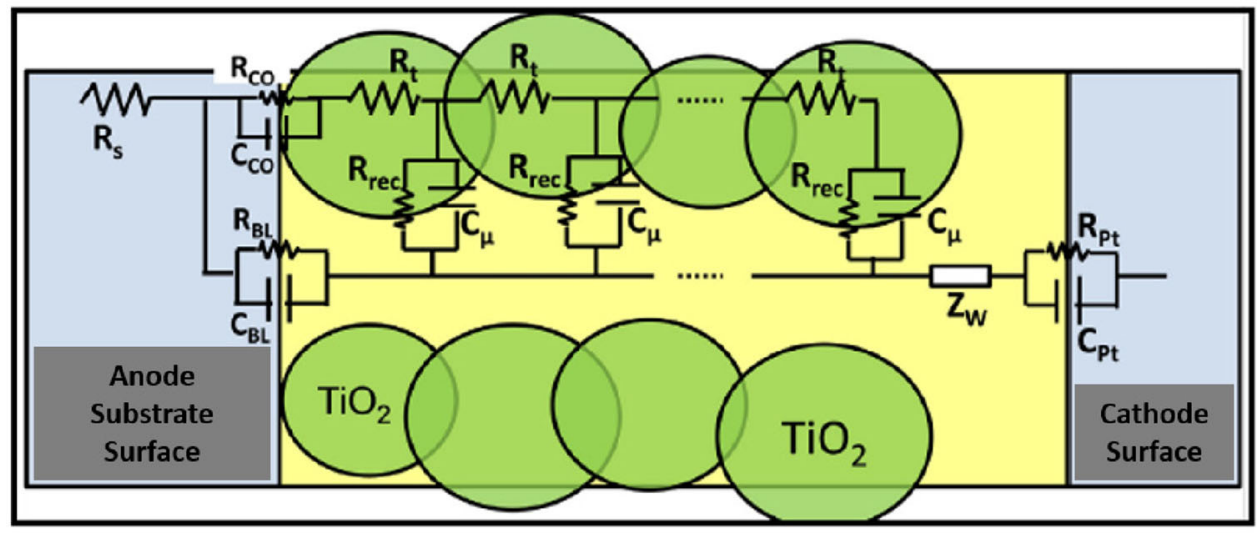

Fig. 5- General transmission line model of DSC. ${ }^{[41]}$ The $\left(R_{\mathrm{rec}}\right)$ is the charge recombination resistance at the $\mathrm{TiO}_{2} / \mathrm{dye}_{\mathrm{e}}$ electrolyte interface; $\left(C_{\mathrm{m}}\right)$ is the chemical capacitance of the $\mathrm{TiO}_{2}$ film; $\left(R_{\mathrm{t}}\right)$ is the transport resistance of electrons in $\mathrm{TiO}_{2}$ film; $Z_{\mathrm{W}}$ is the Warburg element showing the Nernst diffusion of $\mathrm{I}_{3}{ }^{-}$in electrolyte; $\left(R_{\mathrm{Pt}}\right)$ and $\left(C_{\mathrm{Pt}}\right)$ are the charge-transfer resistance and double-layer capacitance at the platinized counter electrode; $\left(R_{\mathrm{BL}}\right)$ and $\left(C_{\mathrm{BL}}\right)$ are the charge-transfer resistance and the corresponding double-layer capacitance at exposed substrate/electrolyte interface; $\left(R_{\mathrm{CO}}\right)$ and $\left(C_{\mathrm{CO}}\right)$ are the resistance and the capacitance at substrate $/ \mathrm{TiO}_{2}$ contact; $R_{\mathrm{s}}$ is the series resistance, including the sheet resistance of FTO-glass, anode substrate, and contact resistance of the cell.

Table II. Electrochemical Impedance Spectroscopy Equivalent Circuit Resistance Components $\boldsymbol{R}_{\mathrm{CE}}, \boldsymbol{R}_{\text {rece }}$, and $\boldsymbol{R}_{\mathrm{s}}$ Average Values Per DSC Type, in Ohms

\begin{tabular}{lcccc}
\hline & $R_{\mathrm{CE}}(\Omega)$ & $R_{\mathrm{rec}}(\Omega)$ & $R_{\mathrm{s}}(\Omega)$ \\
\hline $1.1 \mu$ m-front & $7.2 \pm 1.5$ & $9.4 \pm 1.9$ & $5.9 \pm 0.7$ & $6.6 \pm 1.0$ \\
$1.1 \mu$ m-back & $2.0 \pm 0.5$ & $9.2 \pm 0.1$ & $7.3 \pm 0.9$ & \\
$0.85 \mu$ m-front & $8.4 \pm 0.1$ & $9.3 \pm 0.5$ & $9.8 \pm 0.9$ & $9.3 \pm 1.1$ \\
$0.85 \mu$ m-back & $2.5 \pm 0.1$ & $8.9 \pm 1.1$ \\
\hline
\end{tabular}

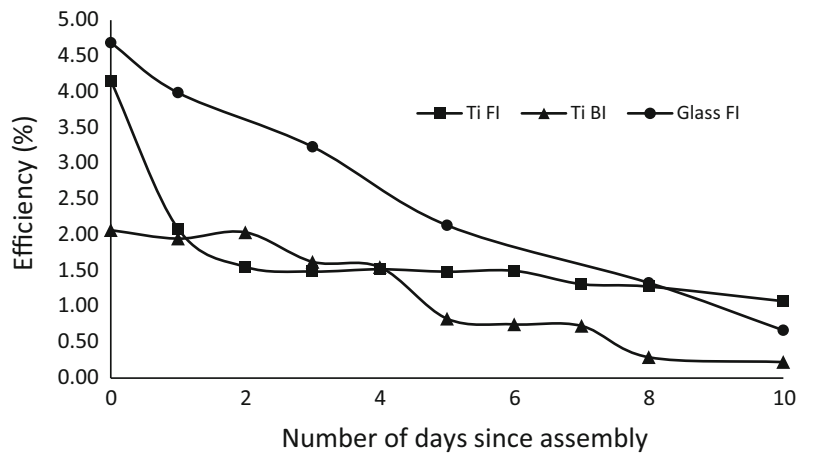

Fig. 6-Efficiency degradation curves of the front- and back-illumination DSCs made with $1.1-\mu$ m-thick sputtered-titanium substrates and of the FI control DSC made on FTO-glass electrodes. The efficiency values were measured without masking for consistency.

Glass-based DSCs also exhibited a decrease in their efficiency, as shown in Figure 6, without any apparent change in the electrolyte color. This efficiency loss is attributed to evaporation of the volatile electrolyte. The rate of evaporation of the electrolyte varied for each glass-based DSC due to manual sealing of each DSC. Since all the DSCs studied were assembled using the same procedure, it is possible to conclude that the decrease in efficiency observed in the case of metal-based DSCs is mainly caused by the reduction of the amount

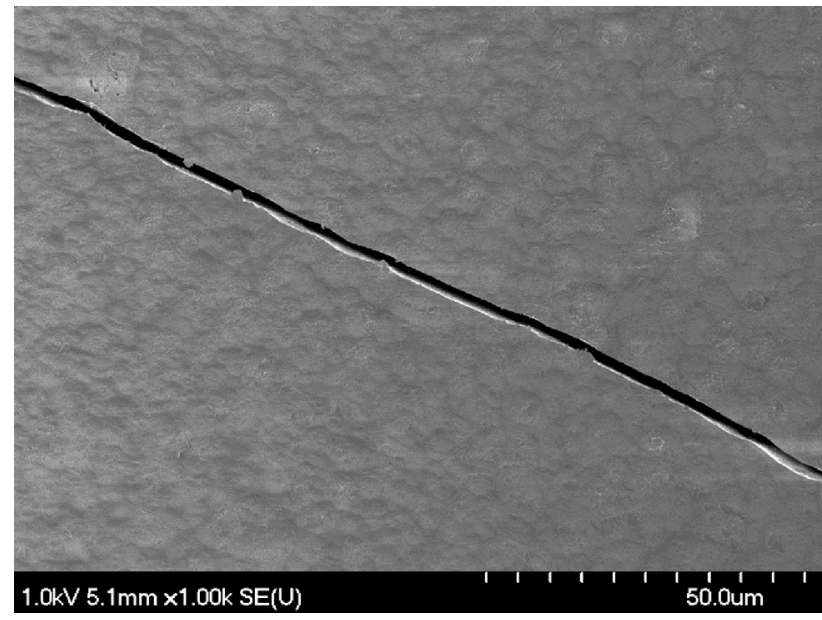

Fig. 7-SEM picture of a surface crack of an anodized aluminum coupon after heating at $723 \mathrm{~K}\left(450{ }^{\circ} \mathrm{C}\right)$ for $30 \mathrm{~min}$.

of triiodide ions in the electrolyte, but also is supplemented by some evaporation of the electrolyte. Nevertheless this efficiency degradation rate is comparable to that of the study of Miettunen et al. for stainless steelbased photo-anodes, where the efficiency was found to drop by 90 pct in 2 weeks, ${ }^{[15]}$ not because of corrosion but rather due to apparent poor sealing. 
Table III. Comparison of Efficiencies of Metal Photo-anode-Based DSCs (BI)

\begin{tabular}{|c|c|c|c|c|c|}
\hline Study & Metallic Electrode & $\eta(\mathrm{pct})$ & Masking Area & Year & Glass Reference \\
\hline \multirow[t]{2}{*}{ This work } & $1.1 \mu \mathrm{m}$-thick titanium-sputtered anodized aluminum & 2.6 & $0.16 \mathrm{~cm}^{2}$ & 2013 & $4.6 \mathrm{pct}$ \\
\hline & $0.85 \mu \mathrm{m}$-thick titanium-sputtered anodized aluminum & 2.9 & & & \\
\hline \multirow[t]{2}{*}{ Watson et al. ${ }^{[5]}$} & pre-painted aluminised steel sputtered with titanium & 2.9 & $\mathrm{n} / \mathrm{a}$ & 2011 & higher \\
\hline & titanium coupon & 3.2 & & & \\
\hline \multirow{3}{*}{ Miettunen et al. ${ }^{[20]}$} & stainless steel & 2.8 & slightly greater than & 2010 & $4.6 \mathrm{pct}$ \\
\hline & inconel & 2.8 & active area & & \\
\hline & titanium foil & 3.4 & & & \\
\hline Jun et $a l_{.}^{[17]}$ & ITO and $\mathrm{SiO}_{x}$ sputtered stainless steel & 6.1 & $\mathrm{n} / \mathrm{a}$ & 2007 & higher \\
\hline Ito et al. ${ }^{[1]}$ & titanium foil & 7.2 & $\mathrm{n} / \mathrm{a}$ & 2006 & $9.9 \mathrm{pct}$ \\
\hline
\end{tabular}

The Glass Ref column states the efficiency of the FTO-glass control DSCs. N/A in the masking area column indicates that this information was not mentioned.

Table IV. Comparison of Efficiencies of Metal Counter Electrode-Based DSCs (FI)

\begin{tabular}{|c|c|c|c|c|c|}
\hline Study & Metallic Electrode & $\eta(\mathrm{pct})$ & Masking Area & Year & Glass Reference \\
\hline \multirow[t]{2}{*}{ This work } & $1.1 \mu \mathrm{m}$-thick titanium-sputtered anodized aluminum & 5.7 & $0.16 \mathrm{~cm}^{2}$ & 2013 & $6.7 \mathrm{pct}$ \\
\hline & $0.85 \mu \mathrm{m}$-thick titanium-sputtered anodized aluminum & 3.9 & & & \\
\hline \multirow[t]{3}{*}{ Chen et al. ${ }^{[18]}$} & nickel & 7.3 & $\mathrm{n} / \mathrm{a}$ & 2010 & - \\
\hline & stainless steel & 6.4 & & & \\
\hline & etched stainless steel & 7.0 & & & \\
\hline Park et al..$^{[21]}$ & titanium-isopropoxide-treated stainless steel & 8.6 & $\mathrm{n} / \mathrm{a}$ & 2008 & - \\
\hline Toivola et al. ${ }^{[19]}$ & stainless steel & 3.6 & $\mathrm{n} / \mathrm{a}$ & 2006 & $4.6 \mathrm{pct}$ \\
\hline \multirow[t]{2}{*}{ Ma et al. ${ }^{[16]}$} & stainless steel & 5.2 & $\mathrm{n} / \mathrm{a}$ & 2004 & $6.0 \mathrm{pct}$ \\
\hline & nickel & 5.1 & & & \\
\hline
\end{tabular}

The Glass Ref column states the efficiency of the FTO-glass control DSCs. N/A in the masking area column indicates that this information was not mentioned.

\section{E. Efficiency Comparison}

Table III compares the efficiency results from the present study with reported values for other metal-based BI DSCs. As shown, the efficiency values obtained in this study are comparable to the other metallic systems. Firstly, a comparison with other titanium-based DSCs is presented. Watson et al. ${ }^{[5]}$ have prepared BI DSCs based on titanium coupons and on pre-painted aluminised steel sputtered with $1.2 \mu \mathrm{m}$ of titanium and obtained maximum efficiencies of 3.2 and 2.9 pct, respectively. Also, Miettunen et al. ${ }^{[20]}$ have prepared BI DSCs directly onto titanium foil and have obtained a maximum efficiency of 3.4 pct. These values are similar to the 2.9 and 2.6 pct average efficiencies obtained for the BI DSCs fabricated in this study with 0.85 and $1.1-\mu \mathrm{m}$ titanium film sputtered on anodized aluminum, respectively. By comparison, the research group of Ito et al. ${ }^{[1]}$ have fabricated optimized BI DSCs based on titanium foil resulting in a high maximum efficiency of 7.2 pct.

Miettunen et al. ${ }^{[20]}$ also used Inconel and stainless steel as photo-anodes obtaining 2.8 pct efficiency in both cases. These efficiencies are lower than the 3.4 pct efficiency obtained on titanium foil in the same paper as described earlier. Jun et al. ${ }^{[17]}$ optimized the efficiency of stainless steel-based BI DSCs by depositing layers of ITO (to provide better conductivity) and $\mathrm{SiO}_{x}$ (to provide better protection) on the stainless steel sub- strates allowing them to achieve a maximum efficiency of 6.1 pct.

A comparison of the efficiency of metal-based FI DSCs is made in Table IV. The average efficiency of the 0.85 and $1.1-\mu \mathrm{m}$-thick titanium film-anodized aluminum-based DSCs fabricated in this work was 3.8 and 5.7 pct, respectively. The thick film efficiency of 5.7 pct and in particular the maximum efficiency obtained for the same device of 7.4 pct are approaching those of rival more expensive counter metal electrodes. Thus, among the counter metallic electrode systems considered, the highest efficiency (8.6 pct) was obtained by Park et al. ${ }^{[21]}$ by sputtering layers of $\mathrm{SiO}_{x}$ and ITO on stainless steel substrates and by spin coating titanium-isopropoxide (TIP) onto the surface prior to $\mathrm{TiO}_{2}$ deposition. Chen et al. ${ }^{[18]}$ have also used stainless steel as base material for DSCs electrodes allowing them to reach efficiencies of 6.4 and 7.0 pct with as-prepared and etched stainless steel electrodes, respectively. Nickel-based DSCs with a maximum efficiency of 7.3 pct have also been fabricated in the same study. By contrast, Toivola et al. ${ }^{[19]}$ and $\mathrm{Ma}$ et al. ${ }^{[16]}$ published lower efficiencies for their stainless steel-based DSCs, namely 3.6 and 5.2 pct, respectively. This difference in efficiency is consistent with the maximum efficiencies reported by these two groups for their reference glass-based cells being 4.6 and 6.0 pct, respectively. 


\section{CONCLUSIONS}

This work has shown that DSCs can be fabricated onto titanium-sputtered anodized aluminum coupons offering a potentially promising BIPV alternative to rigid and costly TCO-glass-based cells in particular considering the wide use of aluminum as construction material. Average efficiencies of 3.8 and 2.9 pct were achieved with $0.85-\mu \mathrm{m}$ thick titanium films for FI and BI cells, respectively. Also, average efficiencies of 5.7 and 2.6 pct were obtained, respectively, with FI and BI DSCs based on 1.1- $\mu$ m-thick titanium films. These values are approaching the average efficiencies obtained on reference FTO-glass cells being 6.7 and 4.6 pet for FI and BI cells, respectively. Moreover, in the case of the FI thick film $(1.1 \mu \mathrm{m})$ DSC, the average efficiency and in particular the maximum efficiency (7.4 pct) was found to be within the same range with values obtained for other metal counter electrode systems that make Ti-sputtered anodized aluminum a promising material given the wide use and lightness of aluminum. However, the metal-based DSCs fabricated in this work exhibited a rapid degradation in their efficiency over time due to the combined effects of reaction of the electrolyte with the aluminum used as a substrate and the evaporation of the electrolyte due to inadequate sealing. It was determined that the electrolyte was able to reach the base aluminum partly due to the porosity of sputtered-titanium columnar deposit and partly due to thermally induced cracks on the anodized alumina. Therefore, further work needs to be done in order to improve the stability of the titanium-coated anodized aluminumbased DSCs by optimizing the microstructure of the titanium film and avoiding cracking through modified sintering protocol such as the ultra-fast NIR sintering process developed by the Worsley group. ${ }^{[23]}$

\section{REFERENCES}

1. S. Ito, N.L. Ha, G. Rothenberger, P. Liska, P. Comte, S.M. Zakeeruddin, P. Péchy, M.K. Nazeeruddin, and M. Grätzel: Chem. Commun. (Camb.), 2006, vol. 38, pp. 4004-06.

2. K. Fan, T. Peng, B. Chai, J. Chen, and K. Dai: Electrochim. Acta, 2010, vol. 55, pp. 5239-44.

3. L.-Y. Lin, C.-P. Lee, K.-W. Tsai, M.-H. Yeh, C.-Y. Chen, R. Vittal, C.-G. Wu, and K.-C. Ho: Prog. Photovolt., 2012, vol. 20 , pp. 181-90.

4. T.-Y. Tsai, C.-M. Chen, S.-J. Cherng, and S.-Y. Suen: Prog. Photovolt., 2013, vol. 21, pp. 226-31.

5. T.M. Watson, G.J. Reynolds, and D.A. Worsley: Ironmak. Steelmak., 2011, vol. 38, pp. 168-72.

6. A. Hagfeldt, G. Boschloo, L. Sun, L. Kloo, and H. Pettersson: Chem. Rev. (Wash. DC), 2010, vol. 110, pp. 6595-663.

7. W.A. Gazotti, A.F. Nogueira, E.M. Girotto, M.C. Gallazzi, and M.-A. De Paoli: Synth. Met., 2000, vol. 108, pp. 151-57.

8. H. Lindström, A. Holmberg, E. Magnusson, L. Malmqvist, and A. Hagfeldt: J. Photochem. Photobiol. A, 2001, vol. 145, pp. 107-12.

9. G. Boschloo, H. Lindström, E. Magnusson, A. Holmberg, and A. Hagfeldt: J. Photochem. Photobiol. A, 2002, vol. 148, pp. 11-15.

10. C. Longo, A.F. Nogueira, and M.-A. De Paoli: J. Phys. Chem. B, 2002, vol. 106, pp. 5925-30.

11. C. Longo, J. Freitas, and M.-A. De Paoli: J. Photochem. Photobiol. A, 2003, vol. 159, pp. 33-39.
12. T. Yamaguchi, N. Tobe, D. Matsumoto, T. Nagai, and H. Arakawa: Sol. Energy Mater. Sol. Cells, 2010, vol. 94, pp. 812-16.

13. H.C. Weerasinghe, P.M. Sirimanne, G.P. Simon, and Y.-B. Cheng: Prog. Photovolt., 2012, vol. 20, pp. 321-32.

14. H.C. Weerasinghe, P.M. Sirimanne, G.P. Simon, and Y.-B. Cheng: J. Phys. Chem. C, 2012, vol. 116, pp. 19053-61.

15. K. Miettunen, J. Halme, and P. Lund: J. Phys. Chem. C, 2009, vol. 113, pp. 10297-302.

16. T. Ma, X. Fang, M. Akiyama, K. Inoue, H. Noma, and E. Abe: $J$. Electroanal. Chem., 2004, vol. 574, pp. 77-83.

17. Y. Jun, J. Kim, and M.G. Kang: Sol. Energy Mater. Sol. Cells, 2007, vol. 91, pp. 779-84.

18. C.-M. Chen, C.-H. Chen, and T.-C. Wei: Electrochim. Acta, 2010, vol. 55 , pp. $1687-95$.

19. M. Toivola, F. Ahlskog, and P. Lund: Sol. Energy Mater. Sol. Cells, 2006, vol. 90, pp. 2881-93.

20. K. Miettunen, X. Ruan, T. Saukkonen, J. Halme, M. Toivola, H. Guangsheng, and P. Lund: J. Electrochem. Soc., 2010, vol. 157, pp. B814-19.

21. J.H. Park, Y. Jun, H.-G. Yun, S.-Y. Lee, and M.G. Kang: $J$. Electrochem. Soc., 2008, vol. 155, pp. F145-49.

22. G.J. Reynolds, T.M. Watson, G. Williams, and D. Worsley: $J$. Electrochem. Soc., 2011, vol. 33, pp. 129-38.

23. T. Watson, I. Mabbett, H. Wang, L. Peter, and D. Worsley: Prog. Photovolt., 2011, vol. 19, pp. 482-86.

24. J.M. Kroon, N.J. Bakker, H.J.P. Smit, P. Liska, K.R. Thampi, P. Wang, S.M. Zakeeruddin, M. Grätzel, A. Hinsch, S. Hore, U. Würfel, R. Sastrawan, J.R. Durrant, E. Palomares, H. Pettersson, T. Gruszecki, J. Walter, K. Skupien, and G. E. Tulloch: Prog. Photovolt., 2007, vol. 15, pp. 1-18.

25. M.J. de Wild-Scholten, and A.C. Veltkamp: Environmental Life Cycle Analysis of Dye Sensitized Solar Devices; Status and Outlook, 22nd European Photovoltaic Solar Energy Conference and Exhibition 2007, Milan, Italy, 3-7 September.

26. T. Watson, G. Reynolds, D. Wragg, G. Williams, and D. Worsley: Int. J. Photoenergy, 2013, vol. 2013, pp. 1-8.

27. S. Roberts, and N. Guariento: Building Integrated Photovoltaics A Handbook, Birkhauser, Boston, 2009.

28. www.aluminum.org: December 29th, 2013.

29. J.R. Davis: Aluminum and Aluminum Alloys, $4^{\text {th }}$ ed., ASM International, Materials Park, OH, 1999.

30. European Aluminum Association Factsheet. http://www.aluminiumaward.eu/2009/upload/files/EAA_building_09_2008.pdf. October 20th, 2013.

31. A. Eftekhari: Nanostructured Materials in Electrochemistry, WileyVCH, Weinheim, 2008.

32. H.J. Snaith: Nat. Photonics, 2012, vol. 6, pp. 337-40.

33. P. Chowdhury, K. Raghuvaran, M. Krishnan, H.C. Barshilia, and K.S. Rajam: Bull. Mater. Sci., 2011, vol. 34, pp. 423-27.

34. C. Cheng, K.Y. Ng, and A.H.W. Ngan: AIP Adv., 2011, vol. 1, p. 042113.

35. C.H. Voon, M.N. Derman, U. Hashim, K.R. Ahmad, and K.L. Foo: J. Nanomater., 2013, vol. 2013, pp. 1-8.

36. S. Yang, F. Wang, Z. Sun, and S. Zhu: Intermetallics, 2012, vol. 10 , pp. 467-71.

37. R. Nédélec, S. Uhlenbruck, D. Sebold, V.A.C. Haanappel, H.-P. Buchkremer, and D. Stöver: J. Power Sources, 2012, vol. 205, pp. 157-63.

38. S.L. Lee, M. Cipollo, D. Windover, and C. Rickard: Surf. Coat. Technol., 1999, vol. 120-121, pp. 44-52.

39. F. Ruske, V. Sittinger, W. Werner, B. Szyszka, K.-U. van Osten, K. Dietrich, and R. Rix: Surf. Coat. Technol., 2005, vol. 20, pp. 236-40.

40. Y. Chiba, A. Islam, Y. Watanabe, R. Komiya, N. Koide, and L. Han: 15th International Photovoltaic Science \& Engineering Conference (PVSEC-15), Shanghai, China, 2005, Technical Digest, p. 665.

41. F. Fabregat-Santiago, J. Bisquert, E. Palomares, L. Otero, D. Kuang, S.M. Zakeeruddin, and M. Grätzel: J. Phys. Chem. C, 2007, vol. 111, pp. 6550-60.

42. N. Parsi Benehkohal, and G.P. Demopoulos: J. Power Sources, 2013, vol. 240, pp. 667-75. 